$\overline{\text { 報 } \quad \text { 文 }}$

\author{
う歯に関与する生活状況とその因子 \\ 石井荘子, 坂 本元子 \\ 和洋女子大学

\section{The Factors and the Living Conditions Related to the Tooth Caries in the Children} \\ Sooko Ishii and Motoko Sakamoto \\ Wayo Women's University
}

In the field of public health in advanced countries, it is said that the most serious problem is an increase in the incidence of tooth caries among children. The causes of caries are attributed not only to unsuitable food intake but also to the general problems arising from living conditions or environmental factors.

In this survey, etiological background of tooth caries was discussed with respect to food intake, environmental factors and the way of living of children in a mountain area and in an urban area.

The prevelance of tooth caries was higher in the mountain area than in the urban area. The amount and frequency of sweets intake is closely related to the number of tooth caries. There was a correlation between the time of $\mathrm{T}$. V. watching and the number of the caries among children in the mountain area. The demand for sweets advertised on T. V. increased in correspondence with the increase in caries. These data also suggest a need to discuss the increase in food intake and the decrease in physical excercises as a consequence of T.V. watching.

Other factors such as teeth brushing after each meal, food preference, and food distribution may be important causes of the tooth caries.

Jap. J. Nutr., 39 ( 4) 157 164 (1981)

目的

近年, 経済の高度成長にともない, 食生活の面にも多様性がみられるようになり, 特に加工食品, 清涼领料, 菓子, スナック類の摂取量が著しく, 食生活・健康面に新しい問題を提供している。このような食品の種類の 増加のなかで，幼児から青年期にかけて諸種の問題がみられるが，特にう歯の罹患率の增加は著しい。

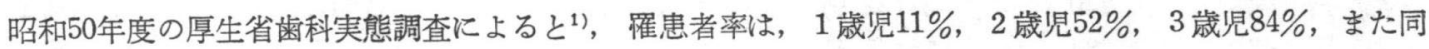
じく 1 人当たりのう歯保有数は 0.3 本, 2.6 本，6.2本とう歯の数は 2 歳から 3 歳にかけて著しく増加している。 さらに 4 歳になると $91.3 \% ， 1$ 人当たり 8.3 本と多くなり，小学校入学時に和けるら歯の罹患率は 90 ～ $98 \%$ に 達しているという状況で, 食生活の関与する疾病として重要な課題となっている。

う歯の增加の原因は，甘いもののとりすぎのような食品面だけの理由によるものではなく，個体（=雪）, 食物, 連鎖状球菌の三要素が交わった場合にできるといわれるが374)，単に直接的な原因だけでなく，子ども をとりまく生活環境, 生活状況, 生活態度など, 他の多くの要因がう歯の発生をまねく食物摂取へ誘導してい ることが考兄られる 
ここでは日常の生活状況のなかで，ら歯の発生に関与する要因をとらえるため，幼児の食生活の面だけでな く, 過去の生活状況, 現在の生活環境, 健康状態など食物摄取にかかわる実態を調査し, さらに地域性を加味 して，ら歯の成因につながる要素を検討した。

万法

対象 : う歯の罹患率の最も高い 4 歳から就学前の 6 歳までの保育所ならびに幼稚園の幼児を対象とした。

調查方法 : 質問紙方式とし, 父兄に記入を依頼した。対象者数は, 東京都内の園児 261 人(以下都市部とす る), 千葉県山間部の園児345人（以下山間部とする）を対象とした。

対象とした 7 の保育園のうち，6つの保育所は，千葉県市原市で，五井の町から小湊線で養老溪谷へ向か う国有林地帯の沿線に点在する部落に所在した。父兄の職業は主として農業で, 林業はほんのわずかであり, 一部は近郊へ通勤するサラリーマンの若い世代が扣り，祖母が主として保育にあたる家庭もみられた。部落に は商店はあるが, 主な食糧の購入は五井の町へ出かける地域であるため, 山間部と名称した。

一方都市部とした保育園は東京都江戸川区小岩に所在し，周囲は商店街で，典型的な下町の様相をもった地 域である。

有効回収率は, 都市部 $95 \%$, 山間部 $82 \%$ で合計 533 人を分析の対象とした。

期間：期間は昭和55年 7 月に実施した。

調査項目 : 1. 身体状況一身長, 体重, 肥満度, 万歯数 2. 生活状沉一テレビ観賞時間, コマーシャル製品に 対する関心度, 歯みがきの状沉 3. 食生活状況一嗜好, 授乳期のミルクの種類, 与方, 離乳の時期, 離乳食 の種類, 抒やっの種類と与方方

集計：集計にはタナックセレクターを使用し，統計処理には Student's t一test を用いた。

\section{結 果}

\section{I 身体状況とう菌保有状況}

1）う歯の罹患状況

ら歯の罹患率は表 1 に示すように，都市部で77.1\%，山間部では94.4\%で，山間部の幼児が高率を示した。 表 1 万歯の保有状況

\begin{tabular}{|c|c|c|c|c|c|}
\hline \multirow{2}{*}{ 地 域 } & \multirow{2}{*}{$\begin{array}{l}\text { 総数 } \\
\text { (人) }\end{array}$} & \multirow{2}{*}{$\begin{array}{c}\text { 非保有者 } \\
\text { (人) }\end{array}$} & 保 & 有者 & （人） \\
\hline & & & 計 & $1 \sim 5$ 本 & 6 本以上 \\
\hline 都 市 部 & 249 & $57(22.9)$ & $192(77.1)$ & $117(47.0)$ & $75(30.1)$ \\
\hline 山 間 部 & 284 & $16(5.6)$ & $268(94.4)$ & $136(47.9)$ & $132(46.5)$ \\
\hline
\end{tabular}

（）：総数に対する百分比\%

また 1 人当たりのう歯の保有者率は都市部，山間部で $1 〜 5$ 本がそれぞれ $47.0 \%$ 及び $47.9 \%$ $9 \%$ あり，6本以上 の保有者率は都市部で $30.1 \%$ ，山間部で $46.5 \%$ と山間部が高い值を示した。う歯の罹患率及び 1 人当たりのう 歯の保有数ともに，山間部は都市部に比べて高い傾向を示している。

2) 肥満の度合いとう歯の罹患状沉

現在の幼児の体格とう歯の関係を検討するために肥満度をとの指標とした2)。表 2 に示す如く，体格では都 
表 2 肥満度の分布状況

\begin{tabular}{|c|c|c|c|c|c|c|}
\hline \multirow{2}{*}{ 肥 満 度 } & \multicolumn{3}{|c|}{ 都 市 部 （人） } & \multicolumn{3}{|c|}{ 山 間 部 (人) } \\
\hline & 計 & う歯保有者 & 非保有者 & 計 & ら歯保有者 & 非保有者 \\
\hline 肥満傾向児 & $14(6.4)$ & $10(5.9)$ & $4(8.3)$ & $12(4.7)$ & $11(4.5)$ & $1(6.3)$ \\
\hline 標 ． 準 & $156(71.6)$ & $122(71.8)$ & $34(70.8)$ & $220(85.3)$ & $205(84.7)$ & $15(93.8)$ \\
\hline そう身傾向児 & $48(22.0) *$ & $38(22.4)$ & $10(20.8)$ & $26(10.1)$ & $26(10.7)$ & 0 \\
\hline 総 数 & 218 & 170 & 48 & 258 & 242 & 16 \\
\hline
\end{tabular}

$*: \mathrm{P}<0.05$

（）：総数に対する百分比\%

市部 $71.6 \%$, 山間部 $85.3 \%$ の幼児が標準範团に出り, 肥満度 $20 \%$ 以上の肥満傾向児では都市部で6. $4 \%$, 山間 部で $4.7 \%$ と少ない傾向を示した。一方都市部ではとう身傾向児が $22 \%$ ，山間部の $10.1 \%$ に比べて有意に高い。 肥満傾向児のう歯の罹患率は両地区とも同じ傾向で低いが，そう身傾向児のう歯の罹患率は山間部より都市部 に高い傾向を示した。

3) 肥満度とう歯保有数

肥満度とう歯保有数との関連をみると, 図 1 亿示すように, 肥満傾向児でう歯 6 本以上西る幼児は都市部 $42.9 \%$, 山間部50\%であった。う歯の保 有数が増すと肥満傾向児も增加する現象 が認められた。そう身傾向児では, 山間 部でう歯の増加とともにとう身傾向児も 増加の傾向を示しているが，都市部では 特徴的なことはみられなかった。

\section{II 生活状況とう歯保有状況}

1) テレビ観賞時間とう歯保有状沉 幼児の情報源として日常接しているテ レビをとりあげ, コマーシャルを通して 紹介される菓子類や即席食品の情報がど のように幼児のう歯に影響を与えている かを、テレビ観賞時間を通して検討した。

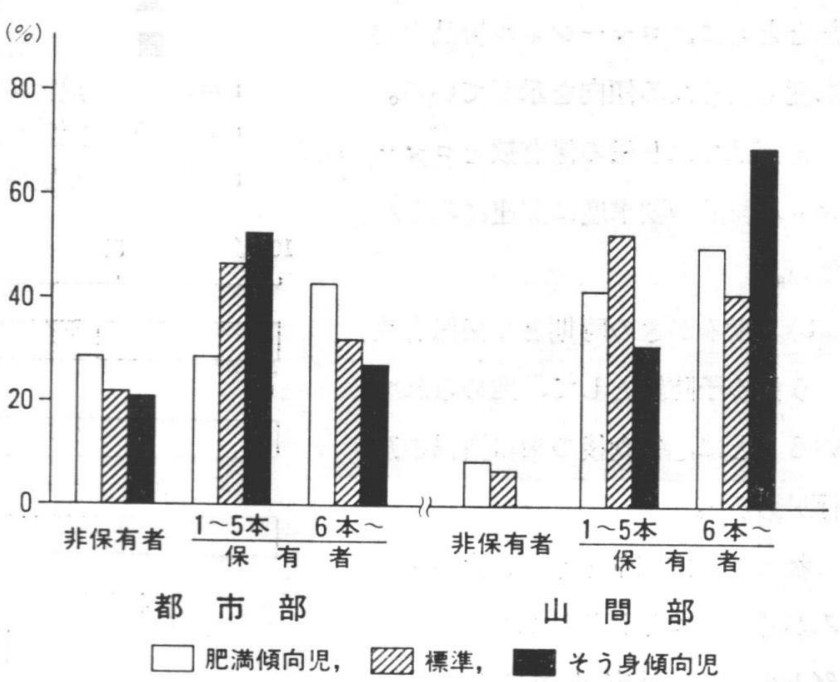

図 1 肥満度とう歯保有数

テレビ観賞時間は都市部で61〜120分が42.6\%，121分以上が36.1\%，山間部ではそれぞれ $39.1 \% ， 45.4 \%$ と 山間部の幼児がややテレビ観賞時間が長い傾向がみられ，ら歯の保有者数との間仙，山間部で $\gamma=0.995(\mathrm{P}<$ $0.05)$, 都市部で $\gamma=0.928$ と高い相関が認められた。

テレビ観賞時間とう歯の保有状況は図 2 に示した。都市部においては 6 本以上の保有者に観賞時間が長くな る傾向がみられた $(\gamma=0.853)$ が有意の差は認められなかった。

しかしう歯のない幼児については観賞時間との関連はみられなかった。

一方山間部では都市部に比し，観賞時間の長い方がら歯の保有者数は多くなったが，6本以上を有する者と 観賞時間の長さでは，相関は認められなかった。

テレビ観賞時間は, 都市部, 山閒部とも，ら歯との関係を強く表しているょうである。 
2) コマーシャル製品の要求度と

ら崡保有数について

テレビコマーシャルの影響をコマ ーシャル製品の要求度から検討し,

図3に示した。

う歯の有無に拘らず都市部の幼児 のコマーシャル製品の要求度コマー シャル製品を見てほしがる度合いに 対して, 山間部の幼児の要求度は低 い傾向を示している。両地区ともら 歯保有者は, コマーシャル製品の要 求度が非保有者に比し高い。

ら歯保有数別に検討すると, 山間 部の幼児は全般にコマーシャル製品 の要求度は低いが，ら歯保有数の増 加とともに, コマーシャル製品の要 求度も高くなる傾向を示している。 都市部ではう歯の保有数とコマー シャル製品の要求度に関連はみられ ない。

3）歯みがさの時期とう歯保有数 ら歯の予防策として, 推められて いることに，毎食後の歯口清掃の励 行がある1リ。

都市部, 山間部とも, 毎食後歯を みがく幼児はそれぞれ $6.8 \% ， 11.3$ \%と少なく，就寝 前でも $61.4 \%$, $57.4 \%$ でる。また山間部では就寝 前よりも朝みがく幼児が $81.3 \%$ と有意に高率を示している。

ら歯の保有数別に検討すると, 都市部では $1 \sim 5$ 本に, 山間部では 6 本以上う歯のある幼児の歯みがきの率 が高くみられる。

\section{III 食生活状況とう畨保有状況}

1）う歯保有数に対する嗜好の影響

ら歯は食品選択にも片寄りを起こす原因にもなり，ひいては嗜好を形成する生理的要因の1つともなる。こ こで表現する嗜好は, 食品の好き嫌いの意味を表す。したか゚って, 食品全般についての好き嫌いの有無と，丂 歯保有数の有無を検討した。

表 3 に示すように, 好き嫌いのある幼児は都市部 $27.2 \%$, 山間部 $28.1 \%$ $\%$ あり, 両地区とも少ない比率を示

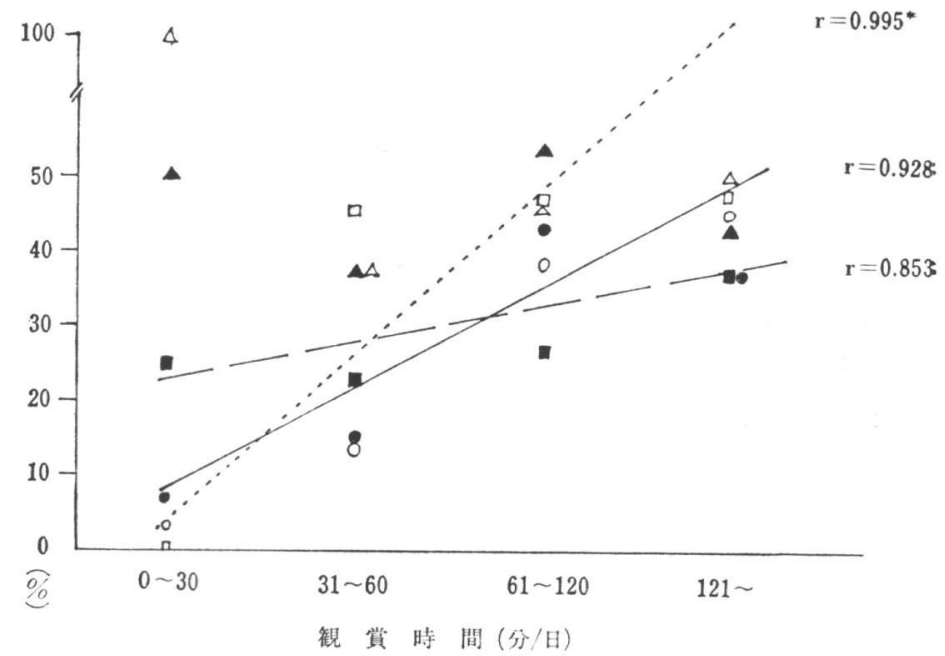
比率を示す) 都市部 山間部

保有者 ○1 5 保有者

-1 5 本保有者 $\triangle 1 \sim 5$ 本保有者 $\mathrm{r}=0.928$ 観賞時間とう歯保有者数（都市部） $\mathrm{r}=0.995 *$ 観賞時間とう歯保有者数（山間部） $\quad *: \mathrm{P}<0.05$ $\mathrm{r}=0.853$ 観賞時間と 6 本以上の保有者数（都市部）

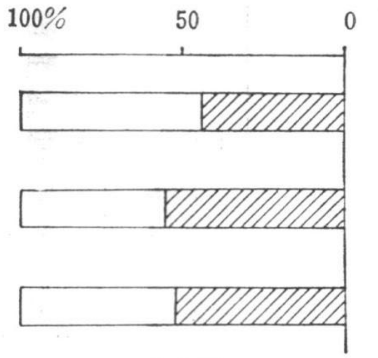

有り

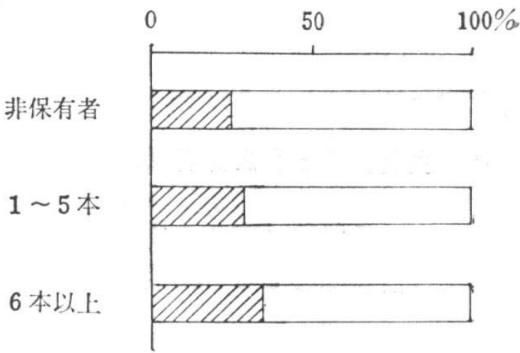

山間部
図 3 ら崡の保有数別コマーシャル製品の要求度
図 2 テレビ観賞時間とう歯の保有状況（百分比は保有者の 
表 3 食生活状況とう歯保有数

\begin{tabular}{|c|c|c|c|c|c|c|c|c|c|c|}
\hline \multirow{3}{*}{ 調 査 } & \multirow{3}{*}{\multicolumn{2}{|c|}{ 項 }} & \multicolumn{4}{|c|}{ 都 市 部 (人) } & \multicolumn{4}{|c|}{ 山 間 部 (人) } \\
\hline & & & \multirow{2}{*}{ 人員計 } & \multirow{2}{*}{ 非保有者 } & \multicolumn{2}{|c|}{ 保有者 } & \multirow{2}{*}{ 計 } & \multirow{2}{*}{ 非保有者 } & \multicolumn{2}{|c|}{ 保有者 } \\
\hline & & & & & $1 \sim 5$ 本 & 6 本以上 & & & $1 \sim 5$ 本 & 6 本以上 \\
\hline \multirow{3}{*}{$\begin{array}{l}\text { 嗜好（好 . } \\
\text { 嫌）の有無 }\end{array}$} & (有 & & $\begin{array}{l}66 \\
\left(27.2^{*}\right)\end{array}$ & $\begin{array}{l}13 \\
\left(22.8^{*}\right)\end{array}$ & $\begin{array}{l}36 \\
\left(31.6^{*}\right)\end{array}$ & $\begin{array}{l}17 \\
\left(23.6^{*}\right)\end{array}$ & $\begin{array}{l}75 \\
\left(28.1^{*}\right)\end{array}$ & $\begin{array}{c}2 \\
\left(13.3^{*}\right)\end{array}$ & $\begin{array}{l}37 \\
\left(29.4^{*}\right)\end{array}$ & $\begin{array}{l}36 \\
\left(28.6^{*}\right)\end{array}$ \\
\hline & 無 & ᄂ & $\begin{array}{l}177 \\
\left(72.8^{*}\right)\end{array}$ & $\begin{array}{l}44 \\
(77.2 *)\end{array}$ & $\begin{array}{l}78 \\
\left(68.4^{*}\right)\end{array}$ & $\begin{array}{l}55 \\
\left(76.4^{*}\right)\end{array}$ & $\begin{array}{l}192 \\
(71.9 *)\end{array}$ & $\begin{array}{l}13 \\
(86.7 *)\end{array}$ & $\begin{array}{l}89 \\
\left(70.6^{*}\right)\end{array}$ & $\begin{array}{l}90 \\
\left(71.4^{*}\right)\end{array}$ \\
\hline & 有無の言 & & 234 & 57 & 114 & 72 & 267 & 15 & 126 & 126 \\
\hline \multirow{3}{*}{$\begin{array}{ll}\text { 間 } & \text { 食 } \\
\text { 与 } & \text { 方 }\end{array}$} & $\begin{array}{l}\text { 手の届 } \\
\text { 所に置 }\end{array}$ & $<$ & 65 & $\begin{array}{l}12 \\
(18.5)\end{array}$ & $\begin{array}{l}33 \\
(50.8)\end{array}$ & $\begin{array}{l}20 \\
(30.8)\end{array}$ & 88 & $\begin{array}{l}3 \\
(3.4)\end{array}$ & $\begin{array}{l}41 \\
(46.6)\end{array}$ & $\begin{array}{l}44 \\
(50.0)\end{array}$ \\
\hline & $\left\{\begin{array}{l}\text { 母 親 } \\
\text { 与 }\end{array}\right.$ & る & 145 & $\begin{array}{l}38 \\
(26.2)\end{array}$ & $\begin{array}{c}67 \\
(46.2)\end{array}$ & $\begin{array}{l}40 \\
(27.6)\end{array}$ & 168 & $\stackrel{11}{(6.5)}$ & $\begin{array}{c}84 \\
(50.0)\end{array}$ & $\begin{array}{c}73 \\
(43.5)\end{array}$ \\
\hline & 幼買 & $\begin{array}{l}b^{3} \\
5\end{array}$ & 34 & $\left(\begin{array}{l}2 \\
5.9\end{array}\right)$ & $\begin{array}{l}20 \\
(58.8)\end{array}$ & $\frac{12}{(35.3)}$ & 26 & $\left(\begin{array}{l}2 \\
7.7\end{array}\right)$ & $\begin{array}{l}11 \\
(42.3)\end{array}$ & $\begin{array}{l}13 \\
(50.0)\end{array}$ \\
\hline \multirow{6}{*}{$\begin{array}{l}\text { 幼览の好 } \\
\text { 导扰やつ }\end{array}$} & $\int r-=$ & $\neq$ & 91 & 20.9 & 40.7 & 38.5 & 83 & 9.6 & 34.9 & 55.4 \\
\hline & 煎 & 餅 & 82 & 20.7 & 48.8 & 30.5 & 106 & 7.5 & 48.1 & 44.3 \\
\hline & クッキー & - & 48 & 18.8 & 33.3 & 47.9 & 54 & 3.7 & 53.7 & 42.6 \\
\hline & 果物 & 物 & 155 & 20.6 & 47.7 & 31.6 & 159 & 6.9 & 50.3 & 42.8 \\
\hline & プリ: & & 100 & 21.0 & 48.0 & 31.0 & 144 & 5.6 & 46.5 & 47.9 \\
\hline & $\mid \begin{array}{ll}\text { フ } & 1 \\
\text { ク } & \text { リー }\end{array}$ & ス & 36 & 22.2 & 58.3 & 19.4 & 199 & 8.0 & 45.2 & 46.7 \\
\hline
\end{tabular}

$(*)$ : 有無の計に対する百分比\%

（）：人員計に対する百分比\%

した。赀好とう歯保有数をみると，好き嫌いのある幼児のうち，都市部，山間部で，非保有者が $22.8 \%, 13.3$ \%に対して，保有数 1〜 5 本，6本以上有する幼児は，都市部で $31.6 \% ， 23.6 \%$, 山間部で $29.4 \% ， 28.6 \%$ と う歯保有者の方が高い傾向を示した。

2) 授乳の種類と方法とう歯の保有数

味覚形成上, 甘味の薄い母乳の方が人工乳上り好ましい7)といらことから, 授乳のミルクの種類と調乳法の 違いによって, う歯の発生に影響があるか否かを検討した。

都市部, 山間部ともに母乳で育った幼児は, ら歯の発生が多い。また調乳法において, 規定通りか, 濃・淡 の度合いを検討したが，う歯との直接な関係は認められなかった。

3）離孚期と離乳法とう歯保有数

離乳に抢ける影響は, 離乳の時期及び離乳法が関与するのではないかと考兄られる゙。

都市部では, 万歯の保有数 6 本以上の群扎いて, 離乳時期が遅くなるにしたがって, 保有者数が増加する 傾向を示した $(\gamma=0.983)$ 。一方山間部では, 離乳時期の早い幼児にもう歯保有者が多い。

4) 間食とう歯保有数

子どもの食事にとって間食は, 3 回の食事と同じ重さで考兄られている。したがって, 間食の与方, 間食 の量及び間食の種類などが問題となる。ここでは間食の与え方，量及び種類などについて検討した。

表 3 に示すように，間食を自由に摂取させるか，母親が与えるか，幼児自身が購入するという間食の与方 別に検討したところ, 都市部の場合には, う歯のない幼児には母親が与える率が高いが，う歯の多い幼児では 
幼児自身が購入する率が高い。山間部では, 万歯のある幼児は母親が与兄るケースよりも, 幼児自身が購入し たり，手の届くところに置いてある場合に保有数が高くみられている。

一方, 間食の回数をみると時期を決めて与兄る場合は, 都市部, 山間部ともにう歯のない幼児に多く, 5歯 の保有数が多い幼児は, ほしがる時に与兄られている傾向がみられ，間食の与方にも規則性をもたせること が必要であろう。

5) おやつの種類とう歯の保有数

幼児のおやつとしては, ケーキ, 煎餅, クッキー, 果物, プリン, アイスクリームなどのらち好まれるすの は, 都市部では果物 $30.3 \%$, プリン $19.5 \%$, ケーキ17.8\%, 煎餅 $16.0 \%$ となっている。山間部ではアイスクリ 一ム $26.7 \%$, 果物 $21.3 \%$, プリン $19.3 \%$ と続いている。これをら歯保有数と検討してみると，直接的な傾向は みられないが，都市部では，クッキー，ケーキを好む幼児にら歯保有者が多く, 山間部でも，ケーキを好む幼 児にう歯保有者が多い傾向を示した。すなわち，甘い技菓子類を好む者に，ら歯の保有が多くみられた。

また好まれる飲物については, 両地区ともジュースが最も好まれているが, う歯保有者とは直接の関連はみ られない。また他の飲物とう歯保有数を検討すると, 都市部では, ら歯の保有数の多い幼児に牛乳は好まれな くて，山間部ではむしろ好む幼児が多くみられ，牛乳の好みとう歯との間には，好ましい影響はみられない。 乳酸领料に関しては, むしろら歯のない幼児に好きな者が多く認められた。

\section{考察}

ら歯発生の背景には, 単に食物摂取だけでなく, 食物攝取を規制する幼児の生活環境, あるいは生活状況な ぞが関与している。したがってう歯の発生に関与する因子をとらえるため, 健康状態, 生活環境など, 食物摂 取にまつわる実態から，う歯の成因につながる内容を検討した。

対象は東京都内の園児 261 人, 千葉県内の園児345人で，身体状況・生活状況・食生活状況などを質問紙方式 で調査した。

乳児のう歯の発生は, 地域差・環境差により左右されるが3(5), その発生率は都市部より農村に多いといわ れる5 。本調査に执いても，ら歯の罹患状況は，都市部より山間部に多い。そこで山間部に多いら歯保有者の 背景について検討をすすめた。山間部の特徵としては,

1. 万歯の保有数の多い幼児は, そう身傾向児に多い。

2. テレビ観賞時間が長く, ら歯の発生に関与すると思われる。

3. コマーシャル製品の要求度は少ないが, 保有数が増加するにともない, 要求度は高い傾向を示す。 などがあげられる。

身体状況で，肥満傾向児がよく問題にされてきたが，今後はう歯をもつそう身傾向児の生活状沉，食生活面 についての検討る必要であろう。

コマーシャル製品の要求度とう歯との直接的な関係は認めがたいが，都市部，山間部の比較では, コマーシ ャル製品の要求度は都市部に高い。このことは, コマーシャル製品がテレビと同時に, その地域で購入できる 環境と, 時間的に購入できない山間部との環境の差とみることもできょう。一方山間部の場合, ら歯の保有者 数が増加するにともない, コマーシャル製品の要求が大きくなる傾向を示すことから, 山間部への食品の流通 が変化することにより要求度の高まりが，う歯の保有数に影響することは推測できる。また小林らの吅やつ の選び方ではコマーシャルの影響は少なかったといっているが, 本調査でも都市部における直接的なテレビの 
影響は少ないと考兄らる。しかしテレビの観賞時間が長くなる程, 保有者が增加することを考えると, 単に コマーシャルの影響ではなく, テレビ観賞時間中の飲食, 活動時間の減少などの背景の検討わ必要であらう。し たがって幼児のテレビ観賞時間を短期間にすることは, 間接的にう歯予防の対策につながることも考えられる。

う歯予防策の 1 つとして，幼児期からの歯みがきがあげられるが7)8)，毎食後みがく幼児は 6.8 11.3\%と 非常に少ない。朝みがく幼児ですう歯保有者が高率を示すことから, 朝のみでなく毎食後みがくことが必要と 思われる7)。

間食の与え方としては，母親が与えるヶースがう歯の保有数を低くしておりの，冨田の報告と同じ結果を得

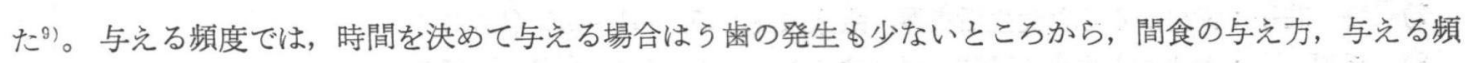
度は規則的に母親の管理のもとに与えられることが望ましい(10)。

幼児に好まれる括やつとしては, 都市部では果物, プリン, 山間部ではアイスクリーム, 果物があげられる が, ケーキ, クッキーの甘い技菓子を好む幼児にう歯の保有数が高い。この結果は小林ら て，甘い扣やつを与えることが，う歯の発生に影響を与えていることは認められる8。

飲物は両地区ともジュースが好まれているが, 万歯の保有数とは直接な関係はない。牛乳の好みについて, この集団ではう歯保有の多いるのに牛乳が好まれているが, 渡辺 ${ }^{11)}$ の報告では牛乳を好む幼児にう歯の保有か゚ 少ないことが示されている。しかし我々の調査項目では好むるのが多種にわたっての記載であるため, 牛乳と ともに他の领物の好みすあることは推測され, 単に牛乳のみの值で比較検討することは困難であろう。

ら歯の発生とその増加については, 単に摂取食品のみならず, 生活状況の影響が大きいことが認められ, 総 合的な予防のための指導が必要であることが認められた。

\section{要 約}

1. 幼児のう歯の増加の要因を, 単に食物拱取, 食生活の面のみにとどまらず, 幼児をとりまく生活環境を 通して検討した。

対象は都内江戸川区内の幼稚園児, 249名, 千葉県市原市の山間部の保育園児, 284名, 計, 533名の幼児に ついて調査した。

2. ら歯の保有者数， 1 人当たりのう歯保有数とも，都市部より山間部に多くみられた。

3. 肥満傾向児，そう身傾向児には，普通児に比し，ら歯保有数が高い結果が得られた。

4. テレビ観賞時間とう崡の関係では, 観賞時間が長くなるほどう歯保有者が増加し, この傾向は特に山間 部にみられた。

一方, コマーシャル製品の要求度は, 万歯の保有数が増加するにとすない高くなることから, テレビの長時 間つ観賞, コマーシャル製品の要求度, う歯の增加, の三者の間に密接な関係があることが示唆された。

5. 間食は保育者の管理のもとに幼児に与兄る方がう歯は少ない。

幼児のう歯の増加には, 摂取食品の質や量のみならず, 生活環境も大きな要因であることが明らかにされ た。

本調査をまとめるに当たり, ご協力いただきました東京都江戸川区, ルンビニー幼稚園, 千葉県市原市, 牛 久保育園, 馬立保育園, 鶴舞保育園, 高滝保育園, 牛久幼稚園, 市東幼稚園の諸先生方, 並びに園児の父兄に 心より感謝いたします。 
交献

1) 厚生省編：日本の子どもたち一その現状と末来一, 厚生白書, p. 49〜52 (1979) 大蔵省印刷局

2）名尾良憲監修 : 栄養過不足疾患, 治療食必携, p. 12～14（1976）医歯薬出版

3）深田英朗 : 食生活の変化と歯科疾患, 臨床栄養, 45, 441 446 (1974)

4）高添一郎：病因を追って，科学するヤクルト，6 (1), 9 (1976)

5）足立己幸編：虫歯が起る時期と実態, 砂糖, p. 30〜37 (1979) 女子栄養大学出版部

6）小林喜美子他：保育園児の夏季の「おやつ」に関する調査（第 2 報），園児の生活環境と「おやつ」 第26回日本栄養改善学会講演集, 190 191 (1979)

7）堀 荘平 : 歯科からみた食生活指導, 臨床栄養, 45, 441〜446 (1974)

8）黒須一夫：おやつと虫歯の予防, 科学するヤクルト，6 (1), 19 (1976)

9）冨田教代 : 幼稚園児のう歯の実態, 間食との関連を中心として, 第26回日本栄養改善学会講演集, p. 194 $\sim 195$ (1979)

10）宮原博子他：保育園児の夏季の「おやつ」に関する調査(第 1 報), 園児の虫歯と「おやつ」, 第26回日本 栄養改善学会講演集, p. 188～189 (1979)

11）渡辺理恵子：幼稚園児の虫歯と食事についての一考察，第26回日本栄養改善学会講演集， p. 192～193 (1979)

（受付 : 昭和 56 年 5 月 11 日） 